\title{
PROVISION OF ACCESS TO THE POSTAL INFRASTRUCTURE: THE EXAMPLE OF LATVIA AND POLAND IN THE CONTEXT OF THE DEVELOPMENT OF THE E-ECONOMY ${ }^{1}$
}

\author{
Anna Drab-Kurowska, PH.D \\ University of Szczecin
}

\begin{abstract}
The article presents the situation on the postal services market of Latvia and Poland in the context of access to postal infrastructure and identified the selected economic policy tools that affect access to postal infrastructure, on the example of Latvia and Poland. In the article the main problem is to indicate that, despite the development of the e-economy and e-services, the role of the state is to provide access to postal infrastructure due to the problem of digital exclusion of citizens who do not have digital competences allowing for efficient functioning in the virtual space. The goals of the presented article are presentation of the situation on the postal services market of Latvia and Poland in the context of access to postal infrastructure and an indication of selected economic policy tools that affect the provision of access to postal infrastructure, on the example of Latvia and Poland. The following basic research hypothesis was adopted: In providing access to the postal infrastructure, the key issue is the identification and implementation of appropriate economic policy tools. Providing access to the postal infrastructure depends on several basic economic policy instruments that can inhibit or stimulate the development of infrastructure. The article shows that for the provision of access to postal infrastructure, they affect to a lesser or larger extent: designated operator, postal market regulator and regulations regarding access to postal infrastructure. The main proposals that will allow to solve the analyzed problem, which include: reacting in a situation when access to infrastructure is insufficient, especially in less urbanized and rural areas, as well as maintaining an appropriate quality level when access is sufficient.
\end{abstract}

Key words: postal market, postal infrastructure, e-economy.

JEL code: L87, L98.

\section{Introduction}

Postal markets in recent years have undergone major transformations. On the one hand, one can speak about the progressing phenomena of globalization (U. Beck, 2018), and on the other hand about the development of modern technologies. In addition, declining tendencies in the area of letterpost items and the decreasing importance of this form of communication for citizens are noticed throughout Europe and worldwide. This does not mean, however, that the role of designated postal operators becomes unnecessary. Along with the development of the digital economy, there are new needs related to access to e-commerce and e-government - especially in rural areas. However, the drop in letter volumes increases the unit costs of maintaining the universal service, especially in less urbanized areas. It should be pointed out that, despite the development of the e-economy and eservices, the role of the state is to provide access to postal infrastructure due to the problem of digital exclusion of citizens who do not have digital competences allowing for efficient functioning in the virtual space. Of course, this problem will decrease in the coming decade, but before it disappears, it is the duty of every EU country to provide citizens with access to postal infrastructure and universal services.

The goals of the presented article are:

1. Presentation of the situation on the postal services market of Latvia and Poland in the context of access to postal infrastructure;

2. An indication of selected economic policy tools that affect the provision of access to postal infrastructure, on the example of Latvia and Poland.

The following basic research hypothesis was adopted:

${ }^{1}$ The project is financed within the framework of the program of the Minister of Science and Higher Education under the name "Regional Excellence Initiative" in the years 2019 - 2022; project number 001/RID/2018/19; the amount of financing PLN 10,684,000.00. 
In providing access to the postal infrastructure, the key issue is the identification and implementation of appropriate economic policy tools.

In order to achieve the indicated goals, the article refers to legal regulations that are a reference point to the problem under examination. This is followed by the characteristics of the postal services markets surveyed. In addition, selected tools of economic policy are presented that directly affect the problem presented in the article.

\section{The situation on the European postal market}

The postal market for many years was treated as a strategic element of each state. Intensive technological changes have compelled national operators to adapt their services to the information society, to use new business opportunities and to pay attention to emerging and dynamically developing indirect and direct competition (e.g. electronic messages). Along with the diversification of postal services, the value of the entire market increased, which resulted in additional interest from the state as an important potential element of budget revenues. The ongoing liberalization processes, which resulted in a slow process of opening up to competition from private operators, had a significant impact on conducting postal activities in the European Union. These activities required the harmonization of national postal law with EU requirements, aimed at strengthening the competitiveness of the market, leading to increased flexibility as well as innovation in postal services. It should also be pointed out that the digital revolution causing the drop in letter volumes generates new areas in which the postal designated operator can play a positive role ( $M$. Falch, A. Henten, 2018). With the growth of e-commerce (in Poland, $25 \%$ only in the last year), there is a growing need to provide regular and affordable supplies to less urbanized and rural areas. Fig. 1 presents the factors affecting the postal market.

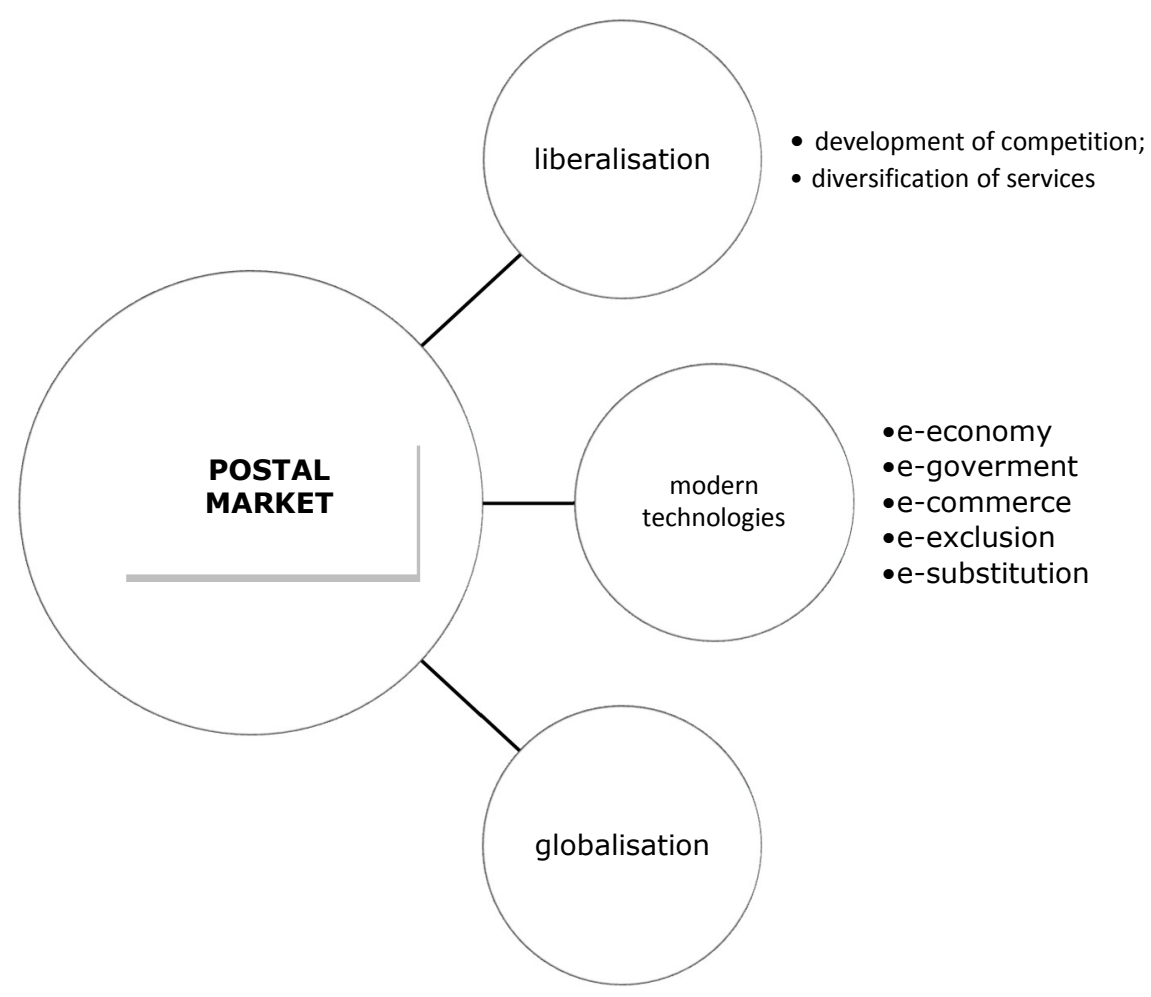

Source: author's study

Fig. 1. Factors affecting the postal market

It should be emphasized that due to the lack of traditional retail outlets, these areas have a steadily growing share in the entire eCommerce purchases. Designated postal operators based on 
their network of post offices and postmen can invest in increasing the capacity of the logistics network to provide an e-commerce parcel service for citizens, uniform in terms of quality and price. In addition, many designated operators in the European Union and in the world offer e-government services performed on behalf of administrative bodies at various levels. They are particularly important in rural areas. These include services related to confirmation of signatures, access to registers, issuing driving licenses, passports and access to computer terminals and support for using the applications made available on them. In Europe, designated operators are playing an increasingly important role in the fight against e-exclusion - there is a possibility of access to e-government services in their facilities.

\section{Selected economic policy tools influencing the provision of access to postal infrastructure}

Providing access to the postal infrastructure depends on several basic economic policy instruments that can inhibit or stimulate the development of infrastructure. The following are the selected tools that undoubtedly have a significant impact on the market analysed in the article. These are:

- the role of the designated operator,

- the role of the postal market regulator and

- regulations regarding access to postal infrastructure.

\subsection{The role of the designated postal operator in the EU}

In recent years, the liberalization of the postal market in the European Union has been completed, during which the concept of a designated operator has been defined. Usually, national operators perform this role. The designated operator function was introduced to neutralize the negative social effects of market liberalization (K. Bodo, 2016). In Latvia, the designated operator is VAD Latvijas Pasts, a company $100 \%$ owned by the state. However, in Poland, it is Poczta Polska SA - the soleshareholder company of the State Treasury. The task of designated operators is to provide universal services in a uniform manner in comparable conditions, and thus:

1. Providing on the territory of the whole country (in rural and urban areas) the distribution of post offices and post boxes

2. Keeping the shipping time indicators and the specific frequency of delivery

3. Provision of services at affordable prices, accepted by the postal market regulator

4. The scope of universal services in Poland and Latvia includes delivery of postal items up to 2 $\mathrm{kg}$, parcels, declared value shipments and registered mail.

\subsection{The role of the postal market regulator in the area with access to postal infrastructure}

Regulatory authorities, by virtue of law, carry out final and binding measures, including, among others, adoption of appropriate law-making procedures and adjudication, which may affect the rights and obligations of entities (Majone G. Surdej A., 2006).

The main reason for giving independence to regulators is the possibility of delegating regulatory powers to specialized institutions. The key goal of delegating regulatory powers is to intensify the credibility of the sectoral policy pursued (F. Gilardi, 2002). The need to ensure the universality of services, especially in less urbanized and rural areas, protection of users' interests, shaping the structure of the postal sector and its competitiveness, ensuring the existence of non-discrimination conditions for all operators, monitoring the designated operator's activities, care for technical progress in the sector, ensuring basic operating conditions, the need to stimulate investments, inform 
about the technical, economic and legal aspects of postal activities, justifies the functioning of regulatory institutions for the postal sector in the context of extensive deregulation and liberalization measures in the postal sector. In addition, the unreliability of the market mechanism, which appears in the postal services markets in the context of less urbanized areas, should be emphasized. The need to maintain the functionality of the infrastructure, the need for universal access to services, the high costs of infrastructure investments and the existence of lost costs eliminate the possibility of introducing competition to certain areas of the post. This also leads to recognition of the legitimacy of the existence of a regulator, which is characterized by monitoring the functioning of the enterprise, collecting information necessary to conduct sectoral policy (D.E.M. Sappington, J. Stiglitz, 1987, R. Sliwa, 2009), as well as securing the interests of service recipients.

In accordance with the requirements of Article 22 of the Postal Directive (Directive 1997), each EU country is required to establish an independent national regulatory authority for the postal sector. Both in Latvia (PUC) and in Poland, there are other sectors in the competences of national regulatory authorities. The regulator should have judicial independence from the government, especially if the government is the owner of a public postal operator. Regarding the independence of the postal market regulator, the following organizational elements should be considered as essential:

- the number of people who manage the work of the regulator institution - the multi-person board is more sTable and independent than one main regulator - in the case of Latvia, this number is 5 , while in Poland - 1, which indicates less stability and independence;

- duration of the term of office - the term of office lasting several years gives the opportunity to implement a coherent long-term policy of the regulator. In both Latvia and Poland, the term of office is 5 years;

- the body appointing the management of the national regulatory authority - the body appointing the management of the national regulatory authority should be a minister other than the minister responsible for supervising the activities of the designated postal operator. Both in the case of Latvia and Poland, the appointing authority is:

- Parliament - Latvia and

- Council of Ministers - Poland.

The key issue in the context of determining the independence of the postal market regulator are the competencies assigned to the regulators. Relations between governments and postal market regulators, both in the context of management of decision-making processes and in the financial area, indicate that in the analysed countries, national regulatory authorities are independent of the control of the ministry responsible for postal services. In addition, both in Latvia and in Poland, the budget of the postal market regulator is approved by Parliament.

\section{Analysis of access to postal infrastructure}

Pursuant to the provisions of the 3rd Directive (Directive 2008), operators appointed in all EU countries have the obligation to provide other operators with selected elements of their own postal infrastructure: a zip code system, an address database for forwarding parcels, post-office boxes, and letterboxes. However, for the other elements of the designated operator's infrastructure, Article 11 of the 3rd Postal Directive only indicates that the Member States will adopt such harmonization measures as are necessary to ensure all users and operators providing postal services access to the postal network on terms that are transparent and non-discriminatory. 
In the report "Main Developments in the Postal Sector (2010-2013)" prepared by the German research institute WIK Consult, commissioned by the European Commission, a detailed analysis was made of the postal infrastructure provisioning by the designated operator in individual countries (Table 1).

Table 1

The scope of providing access to postal infrastructure in EU countries

\begin{tabular}{|c|c|c|}
\hline \multicolumn{3}{|c|}{ The scope of providing access to postal infrastructure in EU countries } \\
\hline \multicolumn{1}{|c|}{ High (7 countries) } & Medium (10 countries) & Low (11 countries) \\
\hline $\begin{array}{l}\text { The Czech Republic, Denmark, } \\
\text { France, Latvia, Luxembourg, } \\
\text { Germany, Slovenia }\end{array}$ & $\begin{array}{c}\text { Austria, Cyprus, Estonia, Greece, } \\
\text { Malta, Poland, Portugal, } \\
\text { Hungary, Great Britain, Italy }\end{array}$ & $\begin{array}{c}\text { Belgium, Bulgaria, Croatia, Finland, Spain, } \\
\text { the Netherlands, Ireland, Latvia, Romania, } \\
\text { Slovakia, Sweden }\end{array}$ \\
\hline
\end{tabular}

None of the European countries decided to provide full access to all elements of the designated operator's network. Latvia provides access to the last stage of service provision, i.e. the delivery stage of the so-called downstream access, which means imposing on the designated operator an obligation to deliver parcels handed to him by other operators providing public services or falling within the scope of public services. Legal regulations regarding the provision of postal infrastructure elements can be divided into three main types (Postal Institute):

- full access to the postal network and infrastructure elements,

- an open directory of postal infrastructure. Belgium and Estonia are an example of applying such regulations.

- provision of specific elements of the postal infrastructure. This type of solution has been implemented, among others in Poland.

On the other hand, point 34 of the preamble to the 3rd Postal Directive emphasizes the obligation to ensure the interoperability of the postal network in the event of several universal service providers with regional postal services networks. In both Latvia and Poland, there is only one designated operator for now. The scope of providing access to postal infrastructure in the countries under examination differs significantly and depends on the organization of a given postal market, as presented in the Table below.

Table 2

\section{Comparison of detailed regulations regarding the provision of access to postal infrastructure in Latvia and Poland}

\begin{tabular}{|l|c|c|c|c|c|}
\hline $\begin{array}{c}\text { Access to } \\
\text { infrastructure : }\end{array}$ & Zip codes & $\begin{array}{c}\text { Post-office } \\
\text { boxes }\end{array}$ & Letterboxes & $\begin{array}{c}\text { Address } \\
\text { database }\end{array}$ & \begin{tabular}{c} 
Returns \\
\hline Latvia
\end{tabular} \\
\hline Poland & + & + & + & - & - \\
\hline
\end{tabular}

Source: WIK Main Developments in the Postal Sector 2010-2013 I Copenhagen Economics (2016) Main developments in the postal sector (2013-2016)

The scope of providing access to postal infrastructure in Poland is wider than in Latvia. This gives more opportunities to alternative operators wishing to operate on the Polish postal market.

Based on the conducted analyses, it has been shown that access to the postal infrastructure is influenced by several basic economic policy tools that may inhibit or stimulate its development. Fig. 2 presents the basic tools. 


\section{ENSURING ACCESS TO THE POSTAL INFRASTRUCTURE}
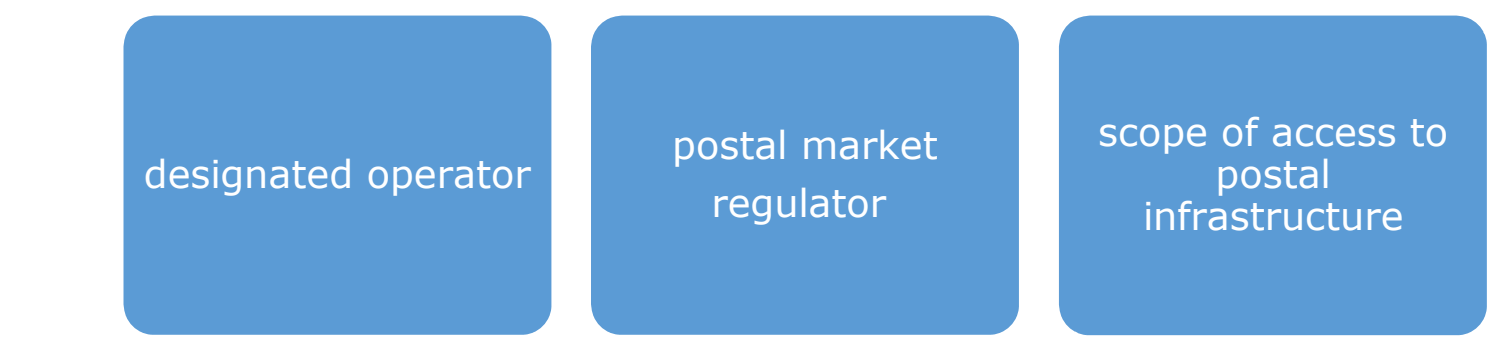

Source: author's study

Fig. 2. Elements affecting access to infrastructure

It is clearly visible that the provision of access to the postal infrastructure is affected to a lesser or greater extent depending on the degree of influence resulting from legal regulations, by indicated tools. The role of the state is:

- responding when access is insufficient, especially in less urbanized and rural areas, and

- maintaining an appropriate quality level when access is sufficient.

That is why it is necessary to constantly monitor and analyse the problem presented in the article, thanks to which the society living in less urbanized and rural areas will not be excluded from basic postal services.

\section{Conclusions}

The full opening of the postal market brings benefits across the entire EU economy, improves the quality of services and reduces their prices. However, the analysis of the possibility of generating profits may lead to discrimination in the access to postal services of selected groups, especially people living in rural, mountainous or sparsely populated areas. An important issue is the obligations imposed on the postal designated operator, which includes the creation of a dense network of post offices and postal outboxes, also in areas with low population density. It is precisely there that postal services are of the utmost importance to provide communication for citizens, opportunities to participate in business life and to provide work, and thus greater social and territorial cohesion at the national level. In accordance with the assumed objectives, the article presents the situation on the postal services market of Latvia and Poland in the context of access to postal infrastructure and identified the selected economic policy tools that affect access to postal infrastructure, on the example of Latvia and Poland. The effect of this study was also to prove the hypothesis that in providing access to the postal infrastructure, the key issue is the identification and implementation of appropriate economic policy tools.

The article shows that for the provision of access to postal infrastructure, they affect to a lesser or larger extent: designated operator, postal market regulator and regulations regarding access to postal infrastructure. The main recommendations that will help solve the problem analyzed in the article are: 1.Responding when access to infrastructure is insufficient, especially in less urbanized and rural areas

2. Maintaining an appropriate quality level when access is sufficient.

In conclusion, it should be pointed out that this article should be treated as a signalling article, indicating the problems of the postal market, which will become the starting point for further broader analysis. 


\section{Bibliography}

1. Beck, U. (2018). What is Globalization?. John Wiley \& Sons.

2. Bodo, K. (2015). Bariery dla otwarcia rynku pocztowego w Polsce (Barriers to the opening of the postal market in Poland). Analiza FOR, 6/2015, p. 10.

3. Copenhagen Economics (2016). Main Developments in the Postal Sector (2013-2016).

4. Dyrektywa 97/67/We Parlamentu Europejskiego i Rady z dnia 15 grudnia 1997 r. w sprawie wspolnych zasad rozwoju rynku wewnętrznego usług pocztowych Wspólnoty oraz poprawy jakości usług (Dz.U. L 15 z 21.1.1998, s. 14)

5. Dyrektywa Parlamentu Europejskiego i Rady 2008/6/WE z dnia 20 lutego 2008 r. zmieniajaca dyrektywę 97/67/WE w odniesieniu do pełnego urzeczywistnienia rynku wewnętrznego usług pocztowych Wspólnoty

6. Falch, M., Henten, A., (2018). Universal Service in a Digital World: The demise of postal services, The 22nd Biennial Conference of the International Telecommunications Society: "Beyond the boundaries: Challenges for business, policy and society", June 24th - 27th, 2018, Seoul, Korea, International Telecommunications Society (ITS), Seoul.

7. GiIardi, F. (2002). Policy Credibility and Delegation of Regulatory Competencies to Independent Agencies: a Comparative Empirical Consideration. "Journal of European Public Policy" 2002, no. 9, p. 874.

8. Majone, G., Surdej, A. (2006). Regulatory Agencies in Economic Governance. The Polish Case in a Comparative Perspective. "KICES Working Papers" No 5.

9. Sappington, D.E.M., Stiglitz, J.(1987). Privatization, Information and Incentives. "Journal of Policy Analysis and Management" No 6 (4).

10.Śliwa, R. (2009). Istota niezależności regulacji w gospodarce opartej na konkurencji. Przykład telekomunikacji (The essence of the independence of regulation in a competitive economy. An example of telecommunications.). Zeszyty Naukowe Małopolskiej Wyższej Szkoły Ekonomicznej w Tarnowie, (2 (13) v.1).

11. WIK-Consult, Main Developments in the Postal Sector (2010-2013) (2013).Study for the European Commission, Directorate General for Internal Market and Services, Bad Hoonef, s. 21. 